\title{
Nutritional support for low birth weight infants: insights from animal studies
}

\author{
$\mathrm{Na} \mathrm{Li}^{1,2}$, Wei Wang ${ }^{1,2}$, Guoyao Wu ${ }^{1,3}$ and Junjun Wang ${ }^{1,2 *}$ \\ ${ }^{1}$ State Key Laboratory of Animal Nutrition, College of Animal Science and Technology, China Agricultural University, Beijing \\ 100193, People's Republic of China \\ ${ }^{2}$ Beijing Advanced Innovation Center for Food Nutrition and Human Health, China Agricultural University, Beijing 100193, \\ People's Republic of China \\ ${ }^{3}$ Department of Animal Science, Texas AGM University, College Station, TX 77843-2471, USA
}

(Submitted 14 November 2016 - Final revision received 30 April 2017 - Accepted 2 May 2017-First published online 13 June 2017)

\section{Abstract}

Infants born with low birth weights ( $<2500 \mathrm{~g}$, LBW), accounting for about $15 \%$ of newborns, have a high risk for postnatal growth failure and developing the metabolic syndromes such as type 2 diabetes, CVD and obesity later in life. Improper nutrition provision during critical stages, such as undernutrition during the fetal period or overnutrition during the neonatal period, has been an important mediator of these metabolic diseases. Considering the specific physiological status of LBW infants, nutritional intervention and optimisation during early life merit further attention. In this review, the physiological and metabolic defects of LBW infants were summarised from a nutritional perspective. Available strategies for nutritional interventions and optimisation of LBW infants, including patterns of nutrition supply, macronutrient proportion, supplementation of amino acids and their derivatives, fatty acids, nucleotides, vitamins, minerals as well as hormone and microbiota manipulators, were reviewed with an aim to provide new insights into the advancements of formulas and human-milk fortifiers.

\section{Key words: Low birth weight: Infants: Growth: Metabolic syndrome: Nutritional support}

According to the WHO, infants with a birth weight $<2500 \mathrm{~g}$, irrespective of gestation, are defined as low birth weight $(\mathrm{LBW})^{(1)}$. Infants with LBW have high morbidity and mortality during the neonatal period as an outcome of intra-uterine growth restriction (IUGR) or preterm birth ${ }^{(2)}$. Although great efforts have been put into nutritional management and clinical support for pregnant women, LBW infants still account for about $15 \%$ of newborns ${ }^{(3)}$. Among all of the environmental factors leading to the occurrence of IUGR, maternal undernutrition has been recognised as the most important. Because of improper nutritional provision during the fetal period, a critical period according to the nutritional programming theory, LBW infants not only show growth failure during the neonatal period, but also lifelong metabolic disturbance ${ }^{(4-6)}$. Therefore, nutritional intervention of LBW infants during their neonatal stage has aroused great attention in recent years. Because of the ethical issues involved, animal models have been widely used to investigate the physiological differences between LBW offspring and normal ones as well as the nutritional support strategies $^{(7)}$.

In this review, we will focus on discussing the physiological differences related to provision and digestion of nutrients between LBW infants and normal infants. Furthermore, we provide information about the current nutritional support given to these LBW infants, with a focus on the neonatal stage.

\section{Consequences of being born with low birth weights Catch-up growth and risks for the metabolic syndromes}

The occurrence of IUGR reflects that the infant probably experienced undernutrition during its development within the uterus. In this case, as a protective mechanism, the fetus prefers to allocate the limited nutrients to vital organs (e.g. the brain) for survival and development, at the expense of somatic growth. Therefore, the growth-hormone system is downregulated, as indicated by the lower serum concentrations of insulin, insulin-like growth factor (IGF) and insulin-like growth factor-binding protein 3 (IGFBP-3) ${ }^{(8-10)}$. By using IUGR piglets as a model, Wang et al. ${ }^{(11)}$ reported that IUGR piglets showed lower concentrations of insulin and IGF-I in the jejunal mucosa when compared with normal littermates. IGF and IGFBP-3 reflect the growth velocity in childhood, and several studies have reported that these two factors can be used as predictors

Abbreviations: Arg, arginine; BCAA, branched-chain amino acids; EN, enteral nutrition; GIT, gastrointestinal tract; Gln, glutamine; IGF, insulin-like growth factor; IUGR, intra-uterine growth restriction; LBW, low birth weights; LC-PUFA, long-chain PUFA; NEC, necrotising enterocolitis; NT, nucleotide; PER, protein: energy ratio; PN, parenteral nutrition; VLBW, very low birth weight.

* Corresponding author: J. Wang, fax +86106273 3688, email jkywjj@hotmail.com 
of catch-up growth of LBW infants during the neonatal period $^{(12-14)}$

Normally, catch-up growth in LBW infants is achieved by overnutrition compensation, and it is postulated to erase the growth deficit generated during the fetal period ${ }^{(1)}$. However, given the fact that IUGR infants are born with lower concentrations of insulin, IGF-I and IGFBP-3, the sudden shift to a normal or overly compensatory diet after birth might increase these parameters during the first 3 months of life ${ }^{(14,15)}$, which will lead to insulin resistance in tissues to prevent hypoglycaemia ${ }^{(1,16)}$. Therefore, catch-up growth actually reflects an insulin-resistance state $^{(17)}$. Meanwhile, preferential abdominal fat deposition, excess circulating lipids and ectopic fat storage were observed in the catch-up growth infants, all of which have been implicated in the risk for developing obesity, type II diabetes (T2D), hypertension and $\mathrm{CVD}^{(18,19)}$. Studies with rodents showed that an accelerated postnatal growth induced excessive adiposity, increased adipocyte sizes and glucose intolerance ${ }^{(20-23)}$. Notably, some researchers stated that growth in different neonatal periods may have different effects on later T2D and CVD risks. It has been reported that catch-up growth that occurred during early infancy (the first 3 months) has a greater programming effect on adiposity and metabolism when compared with growth in later stages of infancy ${ }^{(1)}$.

Furthermore, previous studies have suggested that small-at-birth people have higher fasting plasma cortisol concentrations in their adult lives and increased adrenal responsivity to adrenocorticotropic hormone stimulation, which can then reduce lean body mass and increase lipid accumulation ${ }^{(24-27)}$. As a consequence, the elevated cortisol levels may present a possible link between LBW and adult metabolic syndrome. During the neonatal period, cortisol might also play a role in limiting IGFBP-3 proteolysis and therefore reducing IGF bioavailability ${ }^{(28)}$ and leading to growth failure in LBW children.

\section{Digestive function deficiency}

Recently, by using different experimental models, it has been reported that LBW offspring such as LBW fetuses, neonates, children or young adults have a higher incidence of short- and long-term dysfunctions in several vital organs, as indicated in Table 1. For example, evidence has shown abnormal brain volumes $^{(29)}$ and muscle fibre distributions ${ }^{(40)}$ of young LBW adults, lower bone quality of preterm children ${ }^{(41)}$ as well as smaller thymic size of IUGR human fetuses ${ }^{(42)}$. Besides lower tissue weight, dysregulated expressions of proteins were observed in the liver, skeletal muscle and small intestine of newborn IUGR pigs ${ }^{(31)}$.

Among these organs, the gastrointestinal tract (GIT) is of paramount importance in postnatal nutrient acquisition. The epithelial barrier of the GIT is involved in the first steps of postnatal immune system maturation, providing protection against food antigens and invasion of environmental micro-organisms ${ }^{(33,45)}$. Most studies on the effect of LBW on GIT health were carried out in animal models, especially on piglets. LBW piglets normally show impaired gastrointestinal development, which further imposes limitations on postnatal body growth and development of other organs $^{(33)}$. Compared with normal-birth weight (NBW) newborns,
LBW piglets show a reduced small intestinal weight and a reduced small intestine:body weight ratio up to $21 \mathrm{~d}$ of age ${ }^{(46)}$. The reduced ratio of intestinal weight:length in these LBW piglets indicates a thinner intestinal wall ${ }^{(32,47)}$. Differences in intestinal architecture between IUGR and NBW neonates were widely documented, indicating that the intestinal absorptive surface was smaller in IUGR piglets during the early days of life, as evidenced by the reduced ratio of intestinal villus height:crypt depth ${ }^{(33,34,45,48-50)}$. This reduction of exchange surface is crucial because of its role in processing dietary nutrients into available molecules and regulating the flux of antigenic material ${ }^{(50)}$. Further proteome analysis of the jejunum of LBW piglets revealed that the expression of key proteins involved in major biological processes such as absorption, digestion and transport of nutrients, cell apoptosis, nutrient metabolism, cellular redox homoeostasis and stress response were affected by birth weight during the first $21 \mathrm{~d}$ of life ${ }^{(46,47,50)}$. Moreover, He et al. ${ }^{(34)}$ have reported that IUGR piglets have a distinct metabolic status compared with NBW piglets at $21 \mathrm{~d}$ of age, with changes related to lipogenesis, lipid oxidation, energy supply and utilisation, amino acid and protein metabolism, and antioxidant ability.

Gut bacterial colonisation of LBW piglets is also altered during the early days of life ${ }^{(45)}$. For example, preterm LBW infants had reduced population levels of strict anaerobes such as Bifidobacterium and Bacteroides, and had a high prevalence of Staphylococcus, Enterobacteriaceae, Enterococcaceae and other lactic acid bacteria including the genus Lactobacillus in a low-diversity bacterial ecosystem ${ }^{(51-53)}$. In summary, these results all suggest that LBW newborns are associated with both immediate and long-term altered intestinal adaptation during the neonatal period.

\section{Possible nutritional interventions for improving growth and health of low birth weight infants}

\section{Appropriate patterns of nutrient delivery}

Parenteral nutrition. During the initial days or weeks of life, GIT impairment in LBW infants usually induces an inability to tolerate enteral feedings, which can be referred to as 'feeding intolerance', as indicated by increased gastric residuals, abdominal distension and/or emesis ${ }^{(54)}$. In this case, parenteral nutrition (PN), supplying essential nutrients either by a central or peripheral intravenous injection $^{(55,56)}$, is considered a useful strategy to avoid feeding intolerance until full enteral nutrition (EN) can be adopted. PN should be started either immediately after birth or within the first $2 \mathrm{~h}$ of life ${ }^{(57)}$. In addition, Valentine et al ${ }^{(58)}$ reported that when PN started within the first $24 \mathrm{~h}$ of life, these small infants had shorter durations of PN administration and achieved full enteral feedings earlier compared with those that started PN more than $24 \mathrm{~h}$ after birth. The early use of PN has been shown to reduce postnatal growth failure and mortality, prevent $\mathrm{N}$ imbalance, prevent essential fatty acid and trace mineral deficiency, and improve growth and neurodevelopmental outcomes ${ }^{(59)}$, without the associated short-term metabolic or clinical side effects ${ }^{(60)}$. In early intravenous nutrition for very low birth weight (VLBW; birth weight $<1500 \mathrm{~g}$ ) infants, the recommended administrations of amino acids, glucose and lipids are $2 \cdot 5-3 \cdot 5,12-18$ and $3 \mathrm{~g} / \mathrm{kg}$ per $\mathrm{d}$, respectively. 
Table 1. Examples of epidemiological and animal studies that reveal alterations in vital organs of low birth weight (LBW) offspring compared with normal ones

\begin{tabular}{|c|c|c|c|c|}
\hline $\begin{array}{l}\text { Compartments } \\
\text { observed }\end{array}$ & Outcomes & Developmental stage & Experimental Model & References \\
\hline Brain & $\begin{array}{l}\text { Reduced volumes of grey and white matter } \\
\text { and ventricular dilatation }\end{array}$ & At 20 years of age & $\begin{array}{l}\text { Preterm young adult with } \\
\text { VLBW }\end{array}$ & Bjuland et al. ${ }^{(29)}$ \\
\hline Liver & $\begin{array}{l}\text { Reduced liver weight; differentially } \\
\text { expressed proteins and activities of key } \\
\text { metabolic enzymes }\end{array}$ & $\begin{array}{l}\text { At } 110 \mathrm{~d} \text { of gestation and } \\
\text { birth }\end{array}$ & IUGR pig & $\begin{array}{l}\text { Liu et al. }{ }^{(30)} \\
\quad \text { Wang et al. }\end{array}$ \\
\hline Intestine & $\begin{array}{l}\text { Smaller tissue weight, thinner intestinal wall } \\
\text { and reduced ratio of intestinal villus } \\
\text { height:crypt; differentially expressed } \\
\text { proteins and metabolic status }\end{array}$ & At birth and $1-21 \mathrm{~d}$ of age & IUGR pig & $\begin{array}{l}\text { Wang et al. } .^{(31)} \\
\text { Wang et al. } \\
\text { Xu et al. } .^{(33)} \\
\text { He et al. }{ }^{(34)}\end{array}$ \\
\hline Kidney & $\begin{array}{l}\text { Lower kidney weight, ratio of kidney weight: } \\
\text { body weight and fewer glomeruli }\end{array}$ & At birth & IUGR rat & Shen et al. ${ }^{(35)}$ \\
\hline Kidney & $\begin{array}{l}\text { Lower glomerular filtration rate; higher urine } \\
\mathrm{Ca} \text { :creatinine ratio, fraction excretion of } \\
\mathrm{Mg} \text { and renal threshold for phosphate }\end{array}$ & At $4-5$ years of age & Preterm children with VLBW & Gheissari et al. ${ }^{(36)}$ \\
\hline Skeletal muscle & $\begin{array}{l}\text { Reduced myofiber numbers; differentially } \\
\text { expressed proteins; increased proportion } \\
\text { of type I fibres and capillary density }\end{array}$ & $\begin{array}{l}\text { At } 60,90 \text { and } 110 \mathrm{~d} \text { of } \\
\text { gestation; at birth and at } \\
1 \mathrm{~d} \text { of age }\end{array}$ & IUGR pig & $\begin{array}{l}\text { Wang et al. } .^{(37)} \\
\text { Wang et al. } \\
\text { Bauer et al. } .^{(38)}\end{array}$ \\
\hline Skeletal muscle & $\begin{array}{l}\text { Decreased muscle mitochondrial content } \\
\text { and impaired respiration in isolated } \\
\text { mitochondria and permeabilised fibres }\end{array}$ & At 14 weeks of age & IUGR mice & Beauchamp et al. ${ }^{(39)}$ \\
\hline Skeletal muscle & $\begin{array}{l}\text { Increased proportion of type IIx fibres, } \\
\text { decreased type Ila fibres and elevated } \\
\text { mean areas of muscle fibres }\end{array}$ & At 19 years of age & LBW young men with SGA & Jensen et al. ${ }^{(40)}$ \\
\hline Bone & $\begin{array}{l}\text { Lower bone strength, quality and bone } \\
\text { transmission time }\end{array}$ & At 11.28 years of age & Preterm and SGA children & Longhi et al. ${ }^{(41)}$ \\
\hline Thymus & A decrease in fetal thymic size & During pregnancy & IUGR human fetus & Cromi et al. ${ }^{(42)}$ \\
\hline Thymus & A smaller proportion of T-cell subsets & $\begin{array}{l}\text { At } 60,90 \text { and } 110 \mathrm{~d} \text { of } \\
\text { gestation }\end{array}$ & IUGR pig fetus & Lin et $a l_{.}^{(43)}$ \\
\hline Thymus & $\begin{array}{l}\text { Decreased thymus and lymphocyte counts } \\
\text { as well as alterations in CD4+ and CD8+ } \\
\text { populations }\end{array}$ & At birth and at $21 \mathrm{~d}$ of age & IUGR rat & Contreras et al. ${ }^{(44)}$ \\
\hline
\end{tabular}

VLBW, very low birth weight, <1500 g; IUGR, intra-uterine growth restriction; SGA, small for gestational age.

The reasonable levels of $\mathrm{Na}, \mathrm{K}, \mathrm{Cl}, \mathrm{Ca}, \mathrm{P}$ and $\mathrm{Mg}$ are assumed to be $3-5,1-2,2-3,75-90,60-67$ and $7 \cdot 5-10 \cdot 5 \mathrm{mg} / \mathrm{kg}$ per $\mathrm{d}$, respectively $^{(61)}$.

In total PN of infants, glucose is the most widely used intravenous carbohydrate for neonates because it is a main energy source and is readily available to the brain. Many other non-glucose carbohydrates such as fructose, galactose, sorbitol, glycerol and ethanol have been used as sources of carbohydrates. However, their effects are considered inferior to glucose ${ }^{(59)}$. Commercial lipid emulsions generally include soyabean oil, mixtures of olive and soyabean oils and mixtures of olive and fish oils ${ }^{(59)}$; the fish oil-based lipid emulsion may be a more effective source ${ }^{(62,63)}$.

Enteral nutrition. Enteral feeding is the preferred pattern of nutrition provision for LBW infants. Human milk is not only the paramount EN source but also a supplier of various bioactive compounds to infants, which play vital roles in regulating GIT development and protection from infections ${ }^{(64)}$. However, it can be accompanied by side effects including feeding intolerance and other aforementioned complications. A combination of $\mathrm{PN}$ and EN is commonly practiced after birth until full EN can be accomplished $^{(57)}$. Once full feedings have been established and $\mathrm{PN}$ has been terminated, EN is fully responsible for providing all nutrients to support normal growth ${ }^{(65)}$. Considering that the maternal milk from preterm mothers provides inadequate quantities of nutrients $^{(66)}$, especially protein ${ }^{(61,66)}$, targeted humanmilk fortifiers are added to either the maternal or the donor milk to meet the nutritional needs of rapidly growing LBW infants ${ }^{(67)}$. It can be advised to supply a fortifier content of up to $1.3 \mathrm{~g}$ of protein $/ 100 \mathrm{ml}$ for these small infants, beginning from the time they can tolerate $50-70 \mathrm{ml} / \mathrm{kg}$ per $\mathrm{d}$ of milk $^{(61)}$. Tolerance formulas including soya-protein, protein-hydrolysate and amino-acid-based formulas can be utilised to promote feeding tolerance in LBW neonates $^{(57)}$.

In preterm formulas, as a reference for LBW infants, the carbohydrate source is a combination of lactose and sucrose ${ }^{(68)}$, considering the inadequate lactase activity of the $\mathrm{GIT}^{(69)}$. A part of the sucrose or lactose in formula could be replaced by easily digestible glucose polymers to ensure low osmolality of formulas ${ }^{(61,68)}$. The protein sources are whey and casein derived from cows' milk, and sometimes soya protein. In addition, the fat source is a mixture of vegetable oils containing 30-40\% medium-chain TAG in lipids to improve fat absorption ${ }^{(61,68)}$.

Continuous and intermittent bolus feeding. Compared with continuous feeding, intermittent bolus feeding is considered to be more effective in shortening the time to establish full enteral feeding, improving feed tolerance and accelerating weight gain in premature LBW infants ${ }^{(70,71)}$. Using the newborn NBW pig as a model, it has been demonstrated that intermittent bolus 
feeding increases protein synthesis to a greater extent than continuous feeding by improving activation of amino acids and insulin-induced translation initiation ${ }^{(72,73)}$. On the other hand, contradictory results have also been reported ${ }^{(74,75)}$. This observation in pigs would also be useful to provide some implications for clinical practice in LBW infants. Dsilna et al. ${ }^{(76)}$ demonstrated that continuous feeding could contribute to reduced behavioural stress response compared with intermittent bolus feeding among premature VLBW infants. In spite of these data, it is still difficult to recommend either method of gavage feeding, and more trials in LBW infants or animals are needed to evaluate the benefits and side effects of both methods.

\section{Macronutrients}

LBW infants are generally fed high-protein/energy formulas to improve their growth rates and $\mathrm{N}$ retention ${ }^{(77-81)}$. For instance, Fenton et al $^{\left({ }^{82)}\right.}$ demonstrated that a higher protein intake $(\geq 3.0$ but $<4.0 \mathrm{~g} / \mathrm{kg}$ BW per d) could accelerate weight gain and $\mathrm{N}$ accretion in formula-fed hospitalised infants, which indicated by an enhancement of postnatal growth. Providing a nutrient-rich formula to preterm infants (20\% energy-enriched and 40-60\% more protein and minerals than term formula) increased body weight, length and head circumference growth during the first 18 months $^{(83)}$. Similar results were shown in a piglet study in which the LBW piglets had a comparable growth rate with the normal piglets when fed a high-protein content diet between 7 and $28 \mathrm{~d}$ of life ${ }^{(84)}$. Han $^{(85)}$ also reported that when LBW piglets received a high-nutrition-level diet with all nutrients at about 1.5-fold those of the control, they had markedly increased weight gain of the psoas major muscle. This was probably due to the enhanced gene expressions of IGF-I, IGF-I receptor and mammalian target of rapamycin ( $m$ TOR).

Another widely used strategy to promote the growth of LBW infants is increasing energy intake. However, it has been stated that the major effect of higher energy intake $(594 v .502 \mathrm{~kJ} / \mathrm{d}$ $(142$ v. $120 \mathrm{kcal} / \mathrm{d}))$ in LBW infants is an increase in fat accretion $^{(77)}$. Studies in experimental animals show that protein/ energy malnutrition can affect the utilisation and deposition of protein and $\mathrm{fat}^{(86)}$. High nutrient intake in IUGR piglets led to abnormal immune function during the suckling period by lowering serum concentrations of cytokines such as TNF and IL- $1 \beta$. Moreover, intense nutrient intake induces excessive oxidative stress ${ }^{(87-89)}$, which can impose a further burden on the immature antioxidant system in LBW offspring ${ }^{(90-92)}$.

Considering the potential risk for inducing metabolic problems, the intensive nutrition strategy might not be a proper nutritional intervention for LBW infants. Research on rats showed that postnatal energy restriction can be considered as an effective strategy to alleviate the metabolic syndromes in LBW offspring, like obesity and diabetes ${ }^{(93-95)}$. Che et al. ${ }^{(96)}$ reported that restricting the intake of 7 -d-old IUGR piglets (approximately $70 \%$ of the control's intake) can improve the antioxidant system at the expense of maintaining a low growth rate in the neonatal phase $^{(97)}$.

It is worth noting that protein:energy ratio (PER) of diets will be important for the relative composition of net protein and fat stored in tissues while considering the different nutritional requirements of growth and maintenance ${ }^{(98)}$. In this case, therefore, an appropriate PER in infant formulas is necessary to maintain a positive $\mathrm{N}$ balance, ensure protein utilisation and prevent excessive fat storage ${ }^{(57,99)}$. The PER of mature human milk ranges from $1 \cdot 3-1 \cdot 8 \mathrm{~g} / 418 \mathrm{~kJ}(100 \mathrm{kcal})$, whereas the ratio ranges from $2 \cdot 2-2 \cdot 5 \mathrm{~g} / 418 \mathrm{~kJ}(100 \mathrm{kcal})$ in standard formulas for normal infants ${ }^{(100)}$. However, a higher PER, approximately $3 \mathrm{~g} / 418 \mathrm{~kJ}$ ( $100 \mathrm{kcal})$, is recommended for preterm LBW infants ${ }^{(57,101)}$, which would lead to increased lean mass with relatively decreased fat deposition ${ }^{(99)}$. Once protein intake is adequate to meet the needs of lean body accretion, excessive energy will primarily lead to relatively more fat deposition ${ }^{(98)}$, and then increase the risk for adult obesity ${ }^{(102)}$. Taken together, the optimal constitution and appropriate PER levels in formulas designed specifically for these LBW infants can be useful in achieving the desired growth rate while avoiding extra stress on their defective metabolic system.

\section{Functional components applied to optimise nutritional support for low birth weights infants}

Functional amino acids and derivatives. Epidemiological and metabolic studies have provided novel insights into alterations in the amino acid profiles in LBW fetuses and neonates. Reduction in the concentrations of the arginine (Arg) family of amino acids (Arg, proline, citrulline, glutamine (Gln)) have been reported in the umbilical vein plasma of fetuses or in the plasma of LBW newborns in humans ${ }^{(103-105)}$, pigs $^{(11,34,106,107)}$ and rats ${ }^{(108)}$. Branched-chain amino acids (BCAA) (leucine, isoleucine, valine) also show lower levels in the plasma of fetuses and neonates born with $\mathrm{LBW}^{(34,103,105,106)}$. All of the above implicate that these functional amino acids could be used as potential biomarkers for designing effective strategies to improve the outcomes in LBW neonates.

L-Arginine. L-Arginine (Arg) is an essential amino acid for the maximal growth of young mammals ${ }^{(109-111)}$. It is an essential precursor for the biological synthesis of important molecules such as glutamate, ornithine, proline, polyamines, creatinine, nitric oxide and agmatine ${ }^{(109,112-114)}$.

A systematic review derived from eighty-three human studies reported that the concentration of Arg was about 0.94 g/1 in preterm transitional milk ${ }^{(115)}$, and the mean milk yield of preterm mothers at 6 weeks postpartum was approximately $541(\mathrm{sD} 460 \cdot 9) \mathrm{ml} / \mathrm{d}^{(116)}$. Therefore, provision of Arg from milk is far from adequate to meet the high requirements of growth and metabolic function in preterm newborns ${ }^{(117)}$. Dietary supplementation of $0.6 \%$ Arg to LBW piglets from 7 to $14 \mathrm{~d}$ of age resulted in increased average daily gain and daily $\mathrm{DM}^{(11)}$. The incidence of diarrhoea dropped by $61.5 \%$, accompanied by increased small intestine weight and mucosal villus height ${ }^{(11)}$. Notably, Arg supplementation was found to effectively reduce the incidence of necrotising enterocolitis (NEC) in premature infants with $\mathrm{LBW}^{(118-120)}$. In addition, a recent study observed daily dosing of Arg ( $145.0 \mathrm{mg} / \mathrm{kg}$ body weight per administration) to LBW piglets, from 1 to $17 \mathrm{~d}$ after birth, had an ability to revert 
some of the abnormalities involving amino acids, energy, lipid and nucleotide (NT) metabolism caused by LBW ${ }^{(121)}$. However, these effects appear to be independent of the growth-regulation system because reduced growth rate is still present in these piglets $^{(121)}$. Therefore, optimisation of Arg dosage and timing should be investigated to achieve desirable effects in LBW neonates.

Glutamine. Gln plays vital roles in maintaining several important functions such as energy metabolism, immune response and cell signalling as well as the synthesis of Arg, NT, hexosamines and glycoproteins ${ }^{(114,122-125)}$. The amount of Gln obtained from milk is far from sufficient in newborns to support the Gln requirements for growth ${ }^{(126)}$. Different studies have all shown that Gln supplementation $(0.3 \mathrm{~g} / \mathrm{kg}$ per $\mathrm{d})$ in formulas can increase the growth rate in LBW infants ${ }^{(127)}$, improve the tolerance to enteral feeding and decrease morbidity during the 1 st month ${ }^{(128-130)}$. A previous study in IUGR piglets found that oral administration of Gln at $0.5 \mathrm{~g} / \mathrm{kg}$ of body weight twice per $\mathrm{d}$ from days 0 to 21 of age could reduce amino acid oxidation, increase growth and reduce preweaning mortality ${ }^{(107)}$. Moreover, oral Gln $(1 \mathrm{~g} / \mathrm{kg}$ body weight every $12 \mathrm{~h}$ ) during days 0 to 14 post weaning in LBW pigs induces an enhanced intestinal immunity by increasing heat shock protein 70 expression as well as the suppression of $\mathrm{NF}-\kappa \mathrm{B}^{(131)}$. Collectively, Gln is likely an effective amino acid to enhance the survival, immune response and postnatal growth of LBW infants.

Branched-chain amino acids. There are three amino acids recognised as BCAA: valine, isoleucine and leucine. They play vital parts in protein synthesis in skeletal muscle. The mechanisms that BCAA are involved in include the mTOR signalling pathway, decreasing rates of protein degradation ${ }^{(132)}$ and regulating cell differentiation and apoptosis ${ }^{(133)}$. Importantly, BCAA are substrates for the synthesis of glutamate and Arg in the metabolic pathway of amino acids ${ }^{(134,135)}$. A recent study using weaned LBW pigs as a model showed that dietary supplementation with $0.35 \%$ L-leucine improved the growth rate of LBW piglets by increasing the levels of phosphorylated mTOR and ribosomal S6 kinase 1, and also by reducing muscle atrophy F-box protein ${ }^{(136)}$. Similar results have also been observed in fetal ${ }^{(137)}$ and postnatal LBW rats ${ }^{(138)}$. Obviously, BCAA, particularly leucine, may have a potential effect on accelerating the early growth rate and protein synthesis in LBW offspring. Given the fact that BCAA play a major role in stimulating protein synthesis in skeletal muscle, the optimal BCAA supplement dosage should depend on whether it provides enough for maximum protein deposition in the skeletal muscle of LBW neonates.

L-Carnitine. L-Carnitine (3-hydroxy-4-N,N,N-trimethylaminobutyric acid) is a water-soluble quaternary amine essential for a series of indispensable functions in the intermediary metabolism of mammals. L-Carnitine serves as a shuttling molecule for the transportation of activated long-chain fatty acids from the cytosol into the mitochondrial matrix to produce energy ${ }^{(139)}$. Preterm infants with LBW problems are at a high risk for carnitine deficiency because of an immature biosynthetic ability, insufficient transplacental transportation and exogenous supplementation $^{(140)}$. A previous investigation implied that routine parenteral supplementation with L-carnitine had no demonstrable effect on growth, apnoea or length in LBW infants ${ }^{(140)}$. Nevertheless, evidence suggests that in piglets, adding $\mathrm{L}$-carnitine to diets could accelerate the rates of protein and fat accretion ${ }^{(139,141,142)}$ by stimulating IGF-I signalling, while inhibiting the expression of pro-apoptotic and atrophyrelated genes or genes of the ubiquitin-proteasome system $^{(139,143)}$. In particular, Losel et al. ${ }^{(144)}$ reported that an oral administration of L-carnitine $(400 \mathrm{mg} / \mathrm{d})$ from 7 to $27 \mathrm{~d}$ of age resulted in an intensified myogenic proliferation in LBW suckling pigs, which demonstrated that increasing enteral L-carnitine could be considered as an effective method to improve growth outcomes of LBW neonates. Therefore, supplemental L-carnitine is recommended in LBW infants, but further clinical trials are needed to focus on the safe dosage and outcomes of L-carnitine usage.

PUFA. The major long-chain PUFA (LC-PUFA) such as arachidonic acid (ARA, $20: 4 n-6)$, EPA (20:5n-3) and DHA (22:6n-3) are essential nutrients for maintaining health, cognition and development during fetal as well as early postnatal life in humans ${ }^{(22,145)}$. Previous evidence illustrated that neonates, including the LBW ones, can synthesise DHA and ARA from essential fatty acids such as linolenic acid ( $n-3$ LC-PUFA) and linoleic acid ( $n-6$ LC-PUFA $)^{(146-148)}$. However, the LC-PUFA synthesis rate in these LBW infants was not enough to meet the requirement for optimal growth and development ${ }^{(146,149,150)}$. The decreased proportion of ARA to linoleic acid as well as DHA to $\alpha$-linolenic acid was seen in the fetal plasma of IUGR pregnancies ${ }^{(151)}$, indicating a deficit in LC-PUFA profiles in the IUGR fetus. Therefore, dietary LC-PUFA supplementation can be considered as an efficient strategy to counteract the defective fatty acid composition of IUGR neonates. In a clinical trial, preterm infants fed with a formula containing DHA (0.16\%) + ARA (0.42\%) for the 1 st year had higher lean body mass and reduced fat mass at 1 year of age ${ }^{(152)}$. A systematic review reported that $\omega$-3 LC-PUFA supplementation was found to reduce the incidence of NEC in extremely preterm infants ( $\leq 32$ weeks $)^{(153)}$. Notably, supplementing fish oil (rich in EPA and DHA) has been considered as a potential nutritional intervention to facilitate catch-up growth with normal body composition in preterm infants ${ }^{(154)}$, because of its effect on suppressing the differentiation of fat cells and fat accumulation $^{(155,156)}$. In addition, EPA and DHA play a key part in mediating inflammatory response, which can in turn improve insulin sensitivity ${ }^{(157,158)}$

Nucleotides. NT are a group of bioactive agents regulating nearly all biochemical processes including transferring chemical energy, biosynthetic pathways and coenzyme components ${ }^{(159)}$. NT account for approximately $20 \%$ of the natural non-protein fractions in milk ${ }^{(160)}$ and play important roles in optimising intestinal and immunological function ${ }^{(161)}$. De novo synthesis, salvage pathways and daily food are sources of NT in mammals ${ }^{(162)}$. Cells of the intestinal mucosa have a limited capability for de novo 
synthesis $^{(163)}$. In a rapid growth stage, exogenous NT would become essential nutrients for optimal function especially when the mucosa has already been damaged, which is typically seen in LBW neonates. Recently, research using LBW pigs as a model showed that when LBW piglets received NT-supplemented formula from 7 to $28 \mathrm{~d}$ of age, intestinal villus height and lactase and maltase activity were improved, which led to a better growth rate ${ }^{(162)}$

Vitamins and minerals. The augmented intakes of $\mathrm{Ca}, \mathrm{P}$, trace elements and vitamins in LBW infants are significantly beneficial in improving postnatal growth outcomes. For instance, bone mineralisation is obviously higher in preterm infants when fed Ca- and P-enriched formulas ${ }^{(164)}$ compared with conventional preterm formulas. LBW formulas could be designed with much higher contents of $\mathrm{Na}$ and $\mathrm{K}$ in order to compensate for reduced kidney function ${ }^{(68,165)}$. Because of a high incidence of vitamin A, $\mathrm{D}$ and $\mathrm{E}$ deficiency in VLBW infants ${ }^{(166,167)}$, addition of these vitamins is essential in parenteral or enteral feedings. Vitamin A supplementation in LBW neonates has the potential to improve lung and visual development ${ }^{(168)}$ as well as to reduce death and retinopathy ${ }^{(169)}$. Similarly, a systematic review showed that, as an antioxidant agent, vitamin $\mathrm{E}$ supplementation in preterm infants was able to reduce the risk for retinopathy and intracranial haemorrhage ${ }^{(170)}$. The addition of vitamin $\mathrm{D}$ contributed to higher levels of serum vitamin $\mathrm{D}^{(171)}$, higher $\mathrm{Ca}$ retention ${ }^{(172)}$, and therefore lower incidence of bone hypomineralisation ${ }^{(173)}$. More clinical trials are still required to determine the optimal regimens for these nutrients.

Probiotics and prebiotics. Compared with adults, the enteric microbiota of infants is extremely unstable in terms of composition because of the fast development of the GIT ${ }^{(174)}$. Lactobacillus supplementation remarkably depresses feeding intolerance ${ }^{(175,176)}$ and increases growth velocity ${ }^{(177)}$ in VLBW infants. Supplementing single-strain Bifidobacterium in early life is able to improve body weight gain of LBW infants ${ }^{(177,178)}$ and promote Bifidobacterium colonisation $^{(179)}$. Furthermore, a meta-analysis of twenty randomised and controlled trials showed reduced risks for NEC and mortality were achieved by Bifidobacterium or Lactobacillus supplementation in preterm VLBW infants ${ }^{(180)}$. Accordingly, the use of nutritional intervention to foster a beneficial intestinal microbiota composition can be a good strategy to prevent potential health problems ${ }^{(181)}$. Multi-strain probiotic combinations have shown greater efficacy than single-strain probiotic supplementation for GIT and immune outcomes in animals and humans ${ }^{(182)}$. A combination of Bifidobacterium and Lactobacillus supplementation is proven to reduce the occurrence of NEC $^{(183,184)}$, mortality ${ }^{(185)}$ and to increase the growth rate ${ }^{(186)}$ in LBW infants.

Supplementation with prebiotics in formulas could promote the growth of beneficial microbes in LBW infants. Generally, prebiotics consist of one or more carbohydrates such as inulin, lactulose, fructo-oligosaccharides (FOS) or galacto-oligosaccharides (GOS). For example, supplementing the preterm formula with a mixture of FOS and GOS may stimulate the growth of Bifidobacteria $^{(187,188)}$, whereas lactulose addition increases the growth of Lactobacillus ${ }^{(189)}$. Moreover, Dilli et al. ${ }^{(190)}$ reported that adding a synbiotic (Bifidobacterium lactis plus inulin) to breastmilk or formula could decrease the risk for NEC in VLBW infants. Similar results were observed by supplementing another kind of synbiotic containing Lactobacillus, Bifidobacterium and $\mathrm{FOS}^{(191)}$. Overall, we can speculate that supplementing probiotics and prebiotics alone, or as a combination, might be useful for optimising the intestinal micro-ecology, GIT health and further stimulating the growth outcomes of LBW offspring.

\section{Hormone regulation}

Leptin. Leptin is a $16-\mathrm{kDa}$ cytokine mainly produced by the adipose tissue and is responsible for the central regulation of food intake and energy balance as well as for enhancing the postnatal maturation of numerous peripheral organs. Its deficiency will lead to morbid obesity and diabetes as well as various neuroendocrine anomalies ${ }^{(192-194)}$. Evidence illustrates that human newborns with LBW show significantly lower serum leptin levels than do normal newborns ${ }^{(195)}$. Studies using pigs as a model confirmed that this reduction may be a result of abnormal hypothalamic distribution of leptin receptors ${ }^{(194)}$ and lower expressions of the leptin gene in perineal adipose tissue $^{(196)}$. In piglets, leptin injection $(0.5 \mathrm{mg} / \mathrm{kg})$ from days 2 to 10 of age can improve body weight and lean mass of LBW piglets by increasing organ weights, like that of the pancreas, liver and lung ${ }^{(194)}$. Interestingly, leptin treatment can normalise the composition of the adipose tissue by decreasing whiteadipocyte density while increasing the individual adipocyte size ${ }^{(194)}$. These findings suggest that leptin treatment in early postnatal life has the potential to correct abnormal fat deposition in LBW offspring through regulation of body weight gain, organ development and body composition.

Insulin and insulin-like growth factor-I. In neonatal miniature pigs, oral insulin administration can stimulate ileal growth and enhance the specific activities of lactase and maltase ${ }^{(197)}$. Several studies demonstrated that an extra addition of IGF-I in infant formula might improve GIT growth and function in newborn colostrum-deprived pigs ${ }^{(198-200)}$. Infusion of IGF-1 ( $\left.4 \mu \mathrm{g} / \mathrm{h}\right)$ to IUGR piglets aged 3-10 d evidently increased the circulating concentration of IGF-I and the rate of weight gain by approximately $10 \%$, because of the increase in protein and fat accretion levels ${ }^{(201)}$. The potential mechanisms of this enhancement contain a stimulated cell proliferation in the $\mathrm{GIT}^{(198)}$, increased brush-border disaccharidase activity ${ }^{(199)}$ and increased intestinal weight and ileal villus height ${ }^{(200)}$. In VLBW infants, continuous insulin infusion (0.05 units/kg per h) from $24 \mathrm{~h}$ after birth to $7 \mathrm{~d}$ of age led to an increase in IGF-I concentrations in the serum at $28 \mathrm{~d}$ and therefore, an increase in both body weight and head circumference ${ }^{(21)}$. Similar insulin therapy (0.025 units/kg per h) reduced the incidence of hyperglycaemia in VLBW infants ${ }^{(202)}$. On the basis of this information, IGF-I and insulin could be two potential growth promoters in LBW offspring during the early postnatal period.

\section{Conclusions and perspectives}

In addition to the reduced growth rate after birth, LBW infants are also born with abnormalities in hormone regulation and nutrient utilisation, all of which might have adverse effects on 
Table 2. Examples of nutrition strategies for improving growth, development and health of low birth weight (LBW) infants

\begin{tabular}{|c|c|c|c|}
\hline Interventions & Experimental model & Feeding methods & Primary benefits/side effects \\
\hline \multicolumn{4}{|c|}{ Appropriate patterns of nutrient delivery } \\
\hline PN & Preterm LBW infant & $\begin{array}{l}\text { Started immediately after birth or within the first } 2 \mathrm{~h} \\
\text { of life }\end{array}$ & Avoiding feed intolerance and achieving full enteral feeding earlier \\
\hline EN & Preterm LBW infant & $\begin{array}{l}\text { A combination of PN and EN after birth until achieving } \\
\text { full enteral feeding; supplementing targeted HMF or } \\
\text { LBW formulas }\end{array}$ & $\begin{array}{l}\text { Providing adequate nutrients to support rapid growth and promoting } \\
\text { feeding tolerance }\end{array}$ \\
\hline Continuous feeding & Preterm LBW infant & Orogastric tube feeding by continuous infusion & Lower stress response \\
\hline Intermittent bolus & Preterm LBW infant & Orogastric tube feeding by intermittent bolus infusion & $\begin{array}{l}\text { Faster time to establish full enteral feeding; improving feed tolerance and } \\
\text { accelerating weight gain; higher stress response }\end{array}$ \\
\hline \multicolumn{4}{|l|}{ Macronutrients } \\
\hline Overnutrition & Preterm LBW infant; LBW piglet & Increasing protein and energy intake & $\begin{array}{l}\text { Accelerating weight gain, brain and muscle development and } \mathrm{N} \text { accretion; } \\
\text { increasing fat accretion, inducing more oxidative stress and abnormal } \\
\text { immune function }\end{array}$ \\
\hline Nutrition restriction & IUGR rat or piglet & Decreasing protein and energy intake & $\begin{array}{l}\text { Alleviating obesity and diabetes; improving the antioxidant system; lower } \\
\text { growth rate }\end{array}$ \\
\hline Higher PER & Preterm infant & Approximately $3 \mathrm{~g} / 418 \mathrm{~kJ}(100 \mathrm{kcal})$ in formulas & Increased lean mass with relatively decreased fat deposition \\
\hline \multicolumn{4}{|l|}{ Amino acids and its derivatives } \\
\hline Arg & LBW piglet & Oral administration/dietary supplementation & Promoting growth rate, GIT health and nutrition metabolism \\
\hline Gln & LBW infant or piglet & Oral administration/dietary supplementation & Increasing growth, intestinal immunity; decreasing FI and mortality \\
\hline Leu & LBW piglet or rat & Dietary supplementation & Improving growth rate and protein synthesis; decreasing muscle atrophy \\
\hline L-Carnitine & LBW piglet & Oral administration/dietary supplementation & $\begin{array}{l}\text { Accelerating the rates of protein and fat accretion, and myogenic } \\
\text { proliferation }\end{array}$ \\
\hline \multicolumn{4}{|r|}{ r } \\
\hline DHA + ARA & Preterm infant & Dietary supplementation & Higher lean body mass and reduced fat mass \\
\hline $\mathrm{EPA}+\mathrm{DHA}$ & Preterm infant & Dietary supplementation & $\begin{array}{l}\text { Suppressing fat accumulation; improving insulin sensitivity; regulating } \\
\text { inflammatory response }\end{array}$ \\
\hline NT & LBW piglet & Dietary supplementation & $\begin{array}{l}\text { Higher growth rate, intestinal villus height as well as lactase and } \\
\text { maltase activity }\end{array}$ \\
\hline \multicolumn{4}{|r|}{ Marcase aviving } \\
\hline $\mathrm{Ca}$ and $\mathrm{P}$ & Preterm LBW infant & Dietary supplementation & Improving bone mineralisation \\
\hline $\mathrm{Na}$ and $\mathrm{K}$ & LBW infant & Dietary supplementation & Normalising kidney function \\
\hline \multicolumn{4}{|l|}{ Vitamins } \\
\hline Vitamin A & Preterm LBW infant & Oral administration/dietary supplementation & Improving mortality, lung and visual development \\
\hline Vitamin E & Preterm LBW infant & Oral administration/dietary supplementation & Reducing the risk for retinopathy and intracranial haemorrhage \\
\hline Vitamin D & Preterm LBW infant & Oral administration/dietary supplementation & Higher Ca retention and lower incidence of bone hypomineralisation \\
\hline \multicolumn{4}{|l|}{ Probiotics/prebiotics } \\
\hline Lactobacillus/Bifidobacterium & LBW or VLBW infant & Oral administration/dietary supplementation & $\begin{array}{l}\text { Increasing the growth velocity and colonisation of beneficial bacteria; } \\
\text { reducing the risk for NEC and mortality }\end{array}$ \\
\hline $\mathrm{FOS}+\mathrm{GOS}$ & LBW or VLBW infant & Oral administration/dietary supplementation & Stimulating the growth of Bifidobacteria \\
\hline Lactulose & LBW or VLBW infant & Oral administration/dietary supplementation & Stimulating the growth of Lactobacillus \\
\hline Synbiotic & LBW or VLBW infant & Oral administration/dietary supplementation & Decreasing the risk for NEC \\
\hline \multicolumn{4}{|l|}{ Hormones } \\
\hline Leptin & LBW piglet & Intramuscular injection & Normalising the composition of the adipose tissue \\
\hline IGF-I & LBW piglet & Oral administration/infusion & Improving body weight gain and intestinal development \\
\hline Insulin & VLBW infant & Oral administration/infusion/dietary supplementation & $\begin{array}{l}\text { Increasing IGF-I concentrations, body weight; reducing the incidence } \\
\text { of hyperglycaemia }\end{array}$ \\
\hline
\end{tabular}

PN, parenteral nutrition; EN, enteral nutrition; HMF, human-milk fortifiers; IUGR: intra-uterine growth restriction; PER, protein:energy ratio; Arg, arginine; GIT, gastrointestinal tract; Gln, glutamine; LC-PUFA, long-chain PUFA; ARA, arachidonic acid; NT, nucleotides; VLBW, very low birth weight, <1500 g; NEC, necrotising enterocolitis; FOS, fructo-oligosaccharides; GOS, galacto-oligosaccharides; ; IGF-I, insulin-like growth factor. 
lifelong health. Considering the physiological defects of LBW infants, nutritional interventions during the neonatal stage should focus on promoting the postnatal growth rate without causing potential metabolic problems. Available nutrition strategies based on the preceding information have been summarised in Table 2 . First, the best pattern of nutrition supply is transitioning from a combination of PN and EN to full enteral feeding during the early life of LBW infants. The benefits and shortcomings of continuous $v$. intermittent bolus feeding needs further consideration. Next, the optimal protein and energy contents in the formulas for LBW infants, based on an appropriate PER, should be adopted for preventing metabolic problems caused by high protein or energy levels. Specifically, some functional components (see Table 2), such as functional amino acids and its derivatives, LC-PUFA, NT, vitamins and minerals, probiotics and prebiotics as well as hormonal manipulators could be used as additives in the formulas and HMF. They could also be used as parenteral nutrients to compensate for congenital physiological defects and improve postnatal outcomes in LBW infants. We believe that a combination of these functional components will contribute to an extra-positive effect on LBW neonates' health and growth. More research is also needed to better understand the molecular and cellular mechanisms by which the mentioned nutrients regulate the short- and long-term growth of LBW infants. Another suggestion for further studies would be identifying the differences in metabolism and nutritional requirements between preterm and term LBW infants, and then designing the corresponding HMF and formulas for these two types of neonates. In addition, when the use of LBW infants is limited, a piglet model would be more suitable for the investigation of clinical nutrition because of high similarity in terms of anatomy, genetics and physiology ${ }^{(203,204)}$, compared with rodent models.

\section{Acknowledgements}

The authors thank Mr Daniel Long and Dr Ying Wang for assistance in manuscript preparation.

This work was supported by the National Natural Science Foundation of China (nos 31272449, 31422052, 31572412 and 31630074), the National Key Research and Development Program of China (2016YFD0500506), the '111' Project (B16044), Jinxinnong University Animal Science Developmental Foundation, Hunan Co-Innovation Center of Animal Production Safety (CICAPS) and Agriculture and Food Research Initiative Competitive Grants (2014-67015-21770, 2015-67015-23276 and 2016-67015-24958) from the United States Department of Agriculture (USDA) National Institute of Food and Agriculture, and Texas A\&M AgriLife Research (H-8200).

The authors' contributions are as follows: J. W. designed the framework of the draft. N. L. and W. W. collected the literature and drafted the manuscript. J. W., G. W. and W. W. revised and finalised the draft

The authors declare that there are no conflicts of interest.

\section{References}

1. Jain V \& Singhal A (2012) Catch up growth in low birth weight infants: striking a healthy balance. Rev Endocr Metab Disord 13, 141-147.
2. Lawn JE, Kerber K, Enweronu-Laryea C, et al. (2010) 3.6 million neonatal deaths - what is progressing and what is not? Semin Perinatol 34, 371-386.

3. World Health Organization (2011) Guidelines on Optimal Feeding of Low Birth-Weight Infants in Low-and MiddleIncome Countries. WHO Guidelines Approved by the Guidelines Review Committee. Geneva: WHO.

4. Garite TJ, Clark R \& Thorp JA (2004) Intrauterine growth restriction increases morbidity and mortality among premature neonates. Am J Obstet Gynecol 191, 481-487.

5. Berends LM, Fernandez-Twinn DS, Martin-Gronert MS, et al. (2013) Catch-up growth following intra-uterine growthrestriction programmes an insulin-resistant phenotype in adipose tissue. Int J Obes (Lond) 37, 1051-1057.

6. Claris O, Beltrand J \& Levy-Marchal C (2010) Consequences of intrauterine growth and early neonatal catch-up growth. Semin Perinatol 34, 207-210.

7. Dinerstein A, Nieto RM, Solana CL, et al. (2006) Early and aggressive nutritional strategy (parenteral and enteral) decreases postnatal growth failure in very low birth weight infants. J Perinatol 26, 436-442.

8. Giudice LC, Dezegher F, Gargosky SE, et al. (1995) Insulinlike growth-factors and their binding-proteins in the term and preterm human fetus and neonate with normal and extremes of intrauterine growth. J Clin Endocrinol Metab $\mathbf{8 0}$, $1548-1555$.

9. Lassarre C, Hardouin S, Daffos F, et al. (1991) Serum insulinlike growth factors and insulin-like growth factor binding proteins in the human fetus. Relationships with growth in normal subjects and in subjects with intrauterine growth retardation. Pediatr Res 29, 219-225.

10. Kajantie E, Dunkel L, Rutanen EM, et al. (2002) IGF-I, IGF binding protein (IGFBP)-3, phosphoisoforms of IGFBP-1, and postnatal growth in very low birth weight infants. J Clin Endocrinol Metab 87, 2171-2179.

11. Wang YX, Zhang LL, Zhou GL, et al. (2012) Dietary L-arginine supplementation improves the intestinal development through increasing mucosal Akt and mammalian target of rapamycin signals in intra-uterine growth retarded piglets. Br J Nutr 108, 1371-1381.

12. Thieriot-Prevost G, Boccara JF, Francoual C, et al. (1988) Serum insulin-like growth factor 1 and serum growthpromoting activity during the first postnatal year in infants with intrauterine growth retardation. Pediatr Res 24, 380-383.

13. Ozkan H, Aydin A, Demir N, et al. (1999) Associations of IGF-I, IGFBP-1 and IGFBP-3 on intrauterine growth and early catch-up growth. Biol Neonate 76, 274-282.

14. Leger J, Noel M, Limal JM, et al. (1996) Growth factors and intrauterine growth retardation. II. Serum growth hormone, insulin-like growth factor (IGF) I, and IGF-binding protein 3 levels in children with intrauterine growth retardation compared with normal control subjects: prospective study from birth to two years of age. Study Group of IUGR. Pediatr Res 40, 101-107.

15. Cianfarani S, Germani D, Rossi $\mathrm{P}$, et al. (1998) Intrauterine growth retardation: evidence for the activation of the insulin-like growth factor (IGF)-related growth-promoting machinery and the presence of a cation-independent IGF binding protein-3 proteolytic activity by two months of life. Pediatr Res 44, 374-380.

16. Cianfarani S, Germani D \& Branca F (1999) Low birthweight and adult insulin resistance: the 'catch-up growth' hypothesis. Arch Dis Child Fetal Neonatal Ed 81, F71-F73.

17. Dulloo AG, Jacquet J, Seydoux J, et al. (2006) The thrifty 'catch-up fat' phenotype: its impact on insulin sensitivity 
during growth trajectories to obesity and metabolic syndrome. Int J Obes (Lond) 30, Suppl. 4, S23-S35.

18. Barker DJP, Osmond C, Forsen TJ, et al. (2005) Trajectories of growth among children who have coronary events as adults. $N$ Engl J Med 353, 1802-1809.

19. Dulloo AG (2006) Regulation of fat storage via suppressed thermogenesis: a thrifty phenotype that predisposes individuals with catch-up growth to insulin resistance and obesity. Horm Res 65, Suppl. 3, 90-97.

20. Crescenzo R, Samec S, Antic V, et al. (2003) A role for suppressed thermogenesis favoring catch-up fat in the pathophysiology of catch-up growth. Diabetes 52, 1090-1097.

21. Habbout A, Li N, Rochette L, et al. (2013) Postnatal overfeeding in rodents by litter size reduction induces major short- and long-term pathophysiological consequences. J Nutr 143, 553-562.

22. Isganaitis E, Jimenez-Chillaron J, Woo M, et al. (2009) Accelerated postnatal growth increases lipogenic gene expression and adipocyte size in low-birth weight mice. Diabetes 58, 1192-1200.

23. Wang J, Tang H, Wang X, et al. (2016) The structural alteration of gut microbiota in low-birth-weight mice undergoing accelerated postnatal growth. Sci Rep 6, 27780.

24. Phillips DI, Barker DJ, Fall CH, et al. (1998) Elevated plasma cortisol concentrations: a link between low birth weight and the insulin resistance syndrome? J Clin Endocrinol Metab $\mathbf{8 3}$, 757-760.

25. Ward AM, Syddall HE, Wood PJ, et al. (2004) Fetal programming of the hypothalamic-pituitary-adrenal (HPA) axis: low birth weight and central HPA regulation. J Clin Endocrinol Metab 89, 1227-1233.

26. Reynolds RM, Walker BR, Syddall HE, et al. (2001) Altered control of cortisol secretion in adult men with low birth weight and cardiovascular risk factors. J Clin Endocrinol Metab 86, 245-250.

27. Phillips DI, Walker BR, Reynolds RM, et al. (2000) Low birth weight predicts elevated plasma cortisol concentrations in adults from 3 populations. Hypertension 35, 1301-1306.

28. Cianfarani S, Geremia C, Scott CD, et al. (2002) Growth, IGF system, and cortisol in children with intrauterine growth retardation: is catch-up growth affected by reprogramming of the hypothalamic-pituitary-adrenal axis? Pediatr Res 51, 94-99.

29. Bjuland KJ, Rimol LM, Lohaugen GC, et al. (2014) Brain volumes and cognitive function in very-low-birth-weight (VLBW) young adults. Eur J Paediatr Neurol 18, 578-590.

30. Liu C, Lin G, Wang X, et al. (2013) Intrauterine growth restriction alters the hepatic proteome in fetal pigs. $J$ Nutr Biochem 24, 954-959.

31. Wang J, Chen L, Li D, et al. (2008) Intrauterine growth restriction affects the proteomes of the small intestine, liver, and skeletal muscle in newborn pigs. J Nutr 138, 60-66.

32. Wang X, Lin G, Liu C, et al. (2014) Temporal proteomic analysis reveals defects in small-intestinal development of porcine fetuses with intrauterine growth restriction. $J$ Nutr Biochem 25, 785-795.

33. Xu RJ, Mellor DJ, Birtles MJ, et al. (1994) Impact of intrauterine growth retardation on the gastrointestinal tract and the pancreas in newborn pigs. J Pediatr Gastroenterol Nutr 18, 231-240.

34. He Q, Ren P, Kong X, et al. (2011) Intrauterine growth restriction alters the metabonome of the serum and jejunum in piglets. Mol Biosyst 7, 2147-2155.

35. Shen Q, Xu H, Wei LM, et al. (2010) A comparative proteomic study of nephrogenesis in intrauterine growth restriction. Pediatr Nephrol 25, 1063-1072.
36. Gheissari A, Naseri F, Pourseirafi H, et al. (2012) Postnatal kidney function in children born very low birth weight. Iran J Kidney Dis 6, 256-261.

37. Wang T, Liu C, Feng C, et al. (2013) IUGR alters muscle fiber development and proteome in fetal pigs. Front Biosci 18, 598-607.

38. Bauer R, Gedrange T, Bauer K, et al. (2006) Intrauterine growth restriction induces increased capillary density and accelerated type I fiber maturation in newborn pig skeletal muscles. J Perinat Med 34, 235-242.

39. Beauchamp B, Ghosh S, Dysart MW, et al. (2015) Low birth weight is associated with adiposity, impaired skeletal muscle energetics and weight loss resistance in mice. Int J Obesity 39, 702-711.

40. Jensen CB, Storgaard H, Madsbad S, et al. (2007) Altered skeletal muscle fiber composition and size precede wholebody insulin resistance in young men with low birth weight. J Clin Endocrinol Metab 92, 1530-1534.

41. Longhi S, Mercolini F, Carloni L, et al. (2015) Prematurity and low birth weight lead to altered bone geometry, strength, and quality in children. J Endocrinol Invest 38, 563-568.

42. Cromi A, Ghezzi F, Raffaelli R, et al. (2009) Ultrasonographic measurement of thymus size in IUGR fetuses: a marker of the fetal immunoendocrine response to malnutrition. Ultrasound Obstet Gynecol 33, 421-426.

43. Lin Y, Wang JJ, Wang XQ, et al. (2013) T cells development is different between thymus from normal and intrauterine growth restricted pig fetus at different gestational stage. Asian-Australas J Anim Sci 26, 343-348.

44. Contreras YM, Yu X, Hale MA, et al. (2011) Intrauterine growth restriction alters T-lymphocyte cell number and dual specificity phosphatase 1 levels in the thymus of newborn and juvenile rats. Pediatr Res 70, 123-129.

45. D'Inca R, Gras-Le Guen C, Che L, et al. (2011) Intrauterine growth restriction delays feeding-induced gut adaptation in term newborn pigs. Neonatology 99, 208-216.

46. Wang JJ, Chen LX, Li DF, et al. (2008) Intrauterine growth restriction affects the proteomes of the small intestine, liver, and skeletal muscle in newborn pigs. J Nutr 138, 60-66.

47. Wang XQ, Wu WZ, Lin G, et al. (2010) Temporal proteomic analysis reveals continuous impairment of intestinal development in neonatal piglets with intrauterine growth restriction. J Proteome Res $\mathbf{9}, 924-935$.

48. Wang T, Huo YJ, Shi F, et al. (2005) Effects of intrauterine growth retardation on development of the gastrointestinal tract in neonatal pigs. Biol Neonate 88, 66-72.

49. Wiyaporn M, Thongsong B \& Kalandakanond-Thongsong S (2013) Growth and small intestine histomorphology of low and normal birth weight piglets during the early suckling period. Livest Sci 158, 215-222.

50. D'Inca R, Kloareg M, Gras-Le Guen C, et al. (2010) Intrauterine growth restriction modifies the developmental pattern of intestinal structure, transcriptomic profile, and bacterial colonization in neonatal pigs. J Nutr 140, 925-931.

51. Jacquot A, Neveu D, Aujoulat F, et al. (2011) Dynamics and clinical evolution of bacterial gut microflora in extremely premature patients. J Pediatr 158, 390-396.

52. Arboleya S, Binetti A, Salazar N, et al. (2012) Establishment and development of intestinal microbiota in preterm neonates. FEMS Microbiol Ecol 79, 763-772.

53. Arboleya S, Solis G, Fernandez N, et al. (2012) Facultative to strict anaerobes ratio in the preterm infant microbiota: a target for intervention? Gut Microbes 3, 583-588.

54. Fanaro S (2013) Feeding intolerance in the preterm infant. Early Hum Dev 89, Suppl. 2, S13-S20. 
55. Ziegler EE, Thureen PJ \& Carlson SJ (2002) Aggressive nutrition of the very low birthweight infant. Clin Perinatol 29, 225-244.

56. Heird WC (2001) Determination of nutritional requirements in preterm infants, with special reference to 'catch-up' growth. Semin Neonatol 6, 365-375.

57. Prince A \& Groh-Wargo S (2013) Nutrition management for the promotion of growth in very low birth weight premature infants. Nutr Clin Pract 28, 659-668.

58. Valentine CJ, Fernandez S, Rogers LK, et al. (2009) Early amino-acid administration improves preterm infant weight. J Perinatol 29, 428-432.

59. Patel P \& Bhatia J (2017) Total parenteral nutrition for the very low birth weight infant. Semin Fetal Neonatal Med 22, 2-7.

60. Moyses H, Johnson M, Leaf A, et al. (2013) Early parenteral nutrition and growth outcomes in preterm infants: a systematic review and meta-analysis. Am J Clin Nutr 97, 816-826.

61. De Curtis M \& Rigo J (2012) The nutrition of preterm infants. Early Hum Dev 88, S5-S7.

62. Gura KM, Lee S, Valim C, et al. (2008) Safety and efficacy of a fish-oil-based fat emulsion in the treatment of parenteral nutrition-associated liver disease. Pediatrics 121, e678-e686.

63. de Meijer VE, Gura KM, Le HD, et al. (2009) Fish oil-based lipid emulsions prevent and reverse parenteral nutritionassociated liver disease: the Boston experience. JPEN J Parenter Enteral Nutr 33, 541-547.

64. Wu WZ, Wang XQ, Wu GY, et al. (2010) Differential composition of proteomes in sow colostrum and milk from anterior and posterior mammary glands. J Anim Sci $\mathbf{8 8}$, 2657-2664.

65. Ziegler EE (2011) Meeting the nutritional needs of the low-birth-weight infant. Ann Nutr Metab 58, Suppl. 1, 8-18.

66. Kuschel CA \& Harding JE (2004) Multicomponent fortified human milk for promoting growth in preterm infants. Cochrane Database Syst Rev, issue 1, CD000343.

67. Groh-Wargo S \& Sapsford A (2009) Enteral nutrition support of the preterm infant in the neonatal intensive care unit. Nutr Clin Pract 24, 363-376.

68. Hay WW Jr \& Hendrickson KC (2017) Preterm formula use in the preterm very low birth weight infant. Semin Fetal Neonatal Med 22, 15-22.

69. Tan-Dy CR \& Ohlsson A (2013) Lactase treated feeds to promote growth and feeding tolerance in preterm infants. Cochrane Database Syst Rev, issue 3, CD004591.

70. Dollberg S, Kuint J, Mazkereth R, et al. (2000) Feeding tolerance in preterm infants: randomized trial of bolus and continuous feeding. J Am Coll Nutr 19, 797-800.

71. Schanler RJ, Shulman RJ, Lau C, et al. (1999) Feeding strategies for premature infants: randomized trial of gastrointestinal priming and tube-feeding method. Pediatrics 103 434-439.

72. Gazzaneo MC, Suryawan A, Orellana RA, et al. (2011) Intermittent bolus feeding has a greater stimulatory effect on protein synthesis in skeletal muscle than continuous feeding in neonatal pigs. $J$ Nutr 141, 2152-2158.

73. El-Kadi SW, Gazzaneo MC, Suryawan A, et al. (2013) Viscera and muscle protein synthesis in neonatal pigs is increased more by intermittent bolus than by continuous feeding. Pediatr Res 74, 154-162.

74. Premji SS \& Chessell L (2011) Continuous nasogastric milk feeding versus intermittent bolus milk feeding for premature infants less than 1500 grams. Cochrane Database Syst Rev, issue 11, CD001819.
75. Dsilna A, Christensson K, Alfredsson L, et al. (2005) Continuous feeding promotes gastrointestinal tolerance and growth in very low birth weight infants. J Pediatr 147, 43-49.

76. Dsilna A, Christensson K, Gustafsson AS, et al. (2008) Behavioral stress is affected by the mode of tube feeding in very low birth weight infants. Clin J Pain 24, 447-455.

77. Kashyap S, Schulze KF, Forsyth M, et al. (1988) Growth, nutrient retention, and metabolic response in low birth weight infants fed varying intakes of protein and energy. J Pediatr 113, 713-721.

78. Kashyap S, Ohira-Kist K, Abildskov K, et al. (2001) Effects of quality of energy intake on growth and metabolic response of enterally fed low-birth-weight infants. Pediatr Res 50, 390-397.

79. Premji SS, Fenton TR \& Sauve RS (2006) Higher versus lower protein intake in formula-fed low birth weight infants. Cochrane Database Syst Rev, issue 1, CD003959.

80. Albertssonwikland $\mathrm{K}$, Wennergren $\mathrm{G}$, Wennergren $\mathrm{M}$, et al. (1993) Longitudinal follow-up of growth in children born small-for-gestational-age. Acta Paediatr 82, 438-443.

81. Thureen P \& Heird WC (2005) Protein and energy requirements of the preterm/low birthweight (LBW) infant. Pediatr Res 57, 95R-98R.

82. Fenton TR, Premji SS, Al-Wassia H, et al. (2014) Higher versus lower protein intake in formula-fed low birth weight infants. Cochrane Database Syst Rev, issue 4, CD003959

83. Young L, Morgan J, McCormick FM, et al. (2012) Nutrientenriched formula versus standard term formula for preterm infants following hospital discharge. Cochrane Database Syst Rev, issue 3, CD004696.

84. Morise A, Seve B, Mace K, et al. (2011) Growth, body composition and hormonal status of growing pigs exhibiting a normal or small weight at birth and exposed to a neonatal diet enriched in proteins. Br J Nutr 105, 1471-1479.

85. Han F (2014) High nutrient intake alters muscular growth and metabolic status of neonatal intra-uterine growth-retarded pigs. 2014 ADSA-ASAS-CSAS Joint Annual Meeting, 20-24 July 2014.

86. Weinkove C, Weinkove EA \& Pimstone BL (1974) Insulin release and pancreatic-islet volume in malnourished rats. $S$ Afr Med J 48, 1888-1888.

87. Feillet-Coudray C, Sutra T, Fouret G, et al. (2009) Oxidative stress in rats fed a high-fat high-sucrose diet and preventive effect of polyphenols: Involvement of mitochondrial and NAD(P)H oxidase systems. Free Radic Biol Med 46, 624-632.

88. Decorde K, Teissedre PL, Sutra T, et al. (2009) Chardonnay grape seed procyanidin extract supplementation prevents high-fat diet-induced obesity in hamsters by improving adipokine imbalance and oxidative stress markers. Mol Nutr Food Res 53, 659-666.

89. Devaraj S, Wang-Polagruto J, Polagruto J, et al. (2008) Highfat, energy-dense, fast-food-style breakfast results in an increase in oxidative stress in metabolic syndrome. Metabolism $\mathbf{5 7}, 867-870$.

90. Hracsko Z, Orvos H, Novak Z, et al. (2008) Evaluation of oxidative stress markers in neonates with intra-uterine growth retardation. Redox Rep 13, 11-16.

91. Wang J, Wu Z, Li D, et al. (2012) Nutrition, epigenetics, and metabolic syndrome. Antioxid Redox Signal 17, 282-301.

92. Wang W, Degroote J, Van Ginneken C, et al. (2016) Intrauterine growth restriction in neonatal piglets affects small intestinal mucosal permeability and mRNA expression of redox-sensitive genes. FASEB J 30, 863-873. 
93. Desai M, Gayle D, Babu J, et al. (2005) Programmed obesity in intrauterine growth-restricted newborns: modulation by newborn nutrition. Am J Physiol Regul Integr Comp Physiol 288, R91-R96.

94. Dai Y, Thamotharan S, Garg M, et al. (2012) Superimposition of postnatal calorie restriction protects the aging male intrauterine growth-restricted offspring from metabolic maladaptations. Endocrinology 153, 4216-4226.

95. Garg M, Thamotharan M, Dai Y, et al. (2013) Glucose intolerance and lipid metabolic adaptations in response to intrauterine and postnatal calorie restriction in male adult rats. Endocrinology 154, 102-113.

96. Che LQ, Xuan Y, Hu L, et al. (2015) Effect of Postnatal nutrition restriction on the oxidative status of neonates with intrauterine growth restriction in a pig model. Neonatology 107, 93-99.

97. Hu L, Liu Y, Yan C, et al. (2015) Postnatal nutritional restriction affects growth and immune function of piglets with intra-uterine growth restriction. Br J Nutr 114, 53-62.

98. Hay WW Jr, Brown LD \& Denne SC (2014) Energy requirements, protein-energy metabolism and balance, and carbohydrates in preterm infants. World Rev Nutr Diet 110, 64-81.

99. Kashyap S (2007) Enteral intake for very low birth weight infants: what should the composition be? Semin Perinatol 31, 74-82.

100. Raiha NC, Fazzolari-Nesci A, Cajozzo C, et al. (2002) Whey predominant, whey modified infant formula with protein/ energy ratio of $1.8 \mathrm{~g} / 100 \mathrm{kcal}$ : adequate and safe for term infants from birth to four months. $J$ Pediatr Gastroenterol Nutr 35, 275-281.

101. Su BH (2014) Optimizing nutrition in preterm infants. Pediatr Neonatol 55, 5-13.

102. Belfort MB, Gillman MW, Buka SL, et al. (2013) Preterm infant linear growth and adiposity gain: trade-offs for later weight status and intelligence quotient. J Pediatr 163, 1564-1569.

103. Sanz-Cortes M, Carbajo RJ, Crispi F, et al. (2013) Metabolomic profile of umbilical cord blood plasma from early and late intrauterine growth restricted (IUGR) neonates with and without signs of brain vasodilation. PLOS ONE 8, e80121.

104. Ivorra C, Garcia-Vicent C, Chaves FJ, et al. (2012) Metabolomic profiling in blood from umbilical cords of low birth weight newborns. J Transl Med 10, 142.

105. Tea I, Le Gall G, Küster A, et al. (2012) ${ }^{1} \mathrm{H}-\mathrm{NMR}-\mathrm{b} a \mathrm{~s} \mathrm{~d}$ metabolic profiling of maternal and umbilical cord blood indicates altered materno-foetal nutrient exchange in preterm infants. PLOS ONE 7, e29947.

106. Lin G, Liu C, Feng C, et al. (2012) Metabolomic analysis reveals differences in umbilical vein plasma metabolites between normal and growth-restricted fetal pigs during late gestation. J Nutr 142, 990-998.

107. Wu G, Bazer FW, Johnson GA, et al. (2011) Triennial growth symposium: important roles for L-glutamine in swine nutrition and production. J Anim Sci 89, 2017-2030.

108. Alexandre-Gouabau MC, Courant F, Le Gall G, et al. (2011) Offspring metabolomic response to maternal protein restriction in a rat model of intrauterine growth restriction (IUGR). J Proteome Res 10, 3292-3302.

109. Flynn NE, Meininger CJ, Haynes TE, et al. (2002) The metabolic basis of arginine nutrition and pharmacotherapy. Biomed Pharmacother 56, 427-438.

110. Visek WJ (1986) Arginine needs, physiological state and usual diets. A reevaluation. J Nutr 116, 36-46.

111. Southern LL \& Baker DH (1983) Arginine requirement of the young pig. J Anim Sci 57, 402-412.

112. Wu GY, Knabe DA \& Kim SW (2004) Arginine nutrition in neonatal pigs. J Nutr 134, 2783s-2790s.
113. Kim SW \& Wu G (2004) Dietary arginine supplementation enhances the growth of milk-fed young pigs. J Nutr 134, 625-630.

114. Wu GY \& Morris SM (1998) Arginine metabolism: nitric oxide and beyond. Biochem J 336, 1-17.

115. Zhang Z, Adelman AS, Rai D, et al. (2013) Amino acid profiles in term and preterm human milk through lactation: a systematic review. Nutrients 5, 4800-4821.

116. Hill PD, Aldag JC, Chatterton RT, et al. (2005) Comparison of milk output between mothers of preterm and term infants: the first 6 weeks after birth. J Hum Lact 21, 22-30.

117. Tomlinson C, Rafii M, Sgro M, et al. (2011) Arginine is synthesized from proline, not glutamate, in enterally fed human preterm neonates. Pediatr Res 69, 46-50.

118. Neu J (2002) Arginine supplementation and the prevention of necrotizing enterocolitis in very low birth weight infants. J Pediatr 140, 389-391.

119. Mitchell K, Lyttle A, Amin H, et al. (2014) Arginine supplementation in prevention of necrotizing enterocolitis in the premature infant: an updated systematic review. $B M C$ Pediatrics 14, 226.

120. Shah P \& Shah V (2007) Arginine supplementation for prevention of necrotising enterocolitis in preterm infants. Cochrane Database Syst Rev, issue 3, CD004339.

121. Getty CM, Almeida FN, Baratta AA, et al. (2015) Plasma metabolomics indicates metabolic perturbations in low birth weight piglets supplemented with arginine. J Anim Sci $\mathbf{9 3}$, 5754-5763.

122. Wang X, Qiao S, Yin Y, et al. (2007) A deficiency or excess of dietary threonine reduces protein synthesis in jejunum and skeletal muscle of young pigs. J Nutr 137, 1442-1446.

123. Wu G, Bazer FW \& Tou W (1995) Developmental changes of free amino acid concentrations in fetal fluids of pigs. $J$ Nutr 125, 2859-2868.

124. Horio Y, Osawa S, Takagaki K, et al. (2008) Glutamine supplementation increases Th1-cytokine responses in murine intestinal intraepithelial lymphocytes. Cytokine 44, 92-95.

125. Wu G (1998) Intestinal mucosal amino acid catabolism. J Nutr 128, 1249-1252.

126. Wu G (2010) Functional amino acids in growth, reproduction, and health. Adv Nutr 1, 31-37.

127. Korkmaz A, Yurdakok M, Yigit S, et al. (2007) Long-term enteral glutamine supplementation in very low birth weight infants: effects on growth parameters. Turk J Pediatr 49, 37-44.

128. Neu J, Roig JC, Meetze WH, et al. (1997) Enteral glutamine supplementation for very low birth weight infants decreases morbidity. J Pediatr 131, 691-699.

129. van den Berg A, van Elburg RM, Westerbeek EA, et al. (2005) Glutamine-enriched enteral nutrition in very-low-birthweight infants and effects on feeding tolerance and infectious morbidity: a randomized controlled trial. Am J Clin Nutr 81, 1397-1404.

130. Vaughn P, Thomas P, Clark R, et al. (2003) Enteral glutamine supplementation and morbidity in low birth weight infants. J Pediatr 142, 662-668.

131. Zhong X, Li W, Huang X, et al. (2012) Effects of glutamine supplementation on the immune status in weaning piglets with intrauterine growth retardation. Arch Anim Nutr 66, 347-356.

132. Davis TA, Fiorotto ML, Burrin DG, et al. (2002) Stimulation of protein synthesis by both insulin and amino acids is unique to skeletal muscle in neonatal pigs. Am J Physiol Endocrinol Metab 282, E880-E890.

133. Lei J, Feng D, Zhang Y, et al. (2012) Nutritional and regulatory role of branched-chain amino acids in lactation. Front Biosci 17, 2725-2739. 
134. Rezaei R, Wang W, Wu Z, et al. (2013) Biochemical and physiological bases for utilization of dietary amino acids by young pigs. J Anim Sci Biotechnol 4, 7.

135. Yuan TL, Zhu YH, Shi M, et al. (2015) Within-litter variation in birth weight: impact of nutritional status in the sow. J Zhejiang Univ Sci B 16, 417-435.

136. Xu W, Bai K, He J, et al. (2016) Leucine improves growth performance of intrauterine growth retardation piglets by modifying gene and protein expression related to protein synthesis. Nutrition 32, 114-121.

137. Zheng C, Huang C, Cao Y, et al. (2009) Branched-chain amino acids reverse the growth of intrauterine growth retardation rats in a malnutrition model. Asian-Australas J Anim Sci 22, 1495-1503.

138. Teodoro GFR, Vianna D, Torres-Leal FL, et al. (2012) Leucine is essential for attenuating fetal growth restriction caused by a protein-restricted diet in rats. J Nutr 142, 924-930.

139. Keller J, Ringseis R, Priebe S, et al. (2011) Dietary L-carnitine alters gene expression in skeletal muscle of piglets. Mol Nutr Food Res 55, 419-429.

140. Whitfield J, Smith T, Sollohub H, et al. (2003) Clinical effects of L-carnitine supplementation on apnea and growth in very low birth weight infants. Pediatrics 111, 477-482.

141. Owen KQ, Nelssen JL, Goodband RD, et al. (2001) Effect of dietary L-carnitine on growth performance and body composition in nursery and growing-finishing pigs. J Anim Sci 79, 1509-1515.

142. Owen KQ, Nelssen JL, Goodband RD, et al. (1996) Effect of L-carnitine and soybean oil on growth performance and body composition of early-weaned pigs. J Anim Sci 74, 1612-1619.

143. Keller J, Ringseis R, Koc A, et al. (2012) Supplementation with l-carnitine downregulates genes of the ubiquitin proteasome system in the skeletal muscle and liver of piglets. Animal 6, 70-78.

144. Losel D, Kalbe C \& Rehfeldt C (2009) L-Carnitine supplementation during suckling intensifies the early postnatal skeletal myofiber formation in piglets of low birth weight. J Anim Sci 87, 2216-2226.

145. Innis SM (2005) Essential fatty acid transfer and fetal development. Placenta 26, S70-S75.

146. Salem N, Wegher B, Mena P, et al. (1996) Arachidonic and docosahexaenoic acids are biosynthesized from their 18-carbon precursors in human infants. Proc Natl Acad Sci U S A 93, 49-54.

147. Uauy R, Mena P, Wegher B, et al. (2000) Long chain polyunsaturated fatty acid formation in neonates: effect of gestational age and intrauterine growth. Pediatr Res 47, 127-135.

148. Carnielli VP, Wattimena DJL, Luijendijk IHT, et al. (1996) The very low birth weight premature infant is capable of synthesizing arachidonic and docosahexaenoic acids from linoleic and linolenic acids. Pediatr Res 40, 169-174.

149. Fleith M \& Clandinin MT (2005) Dietary PUFA for preterm and term infants: review of clinical studies. Crit Rev Food Sci Nutr 45, 205-229.

150. Uauy R \& Mena P (2015) Long-chain polyunsaturated fatty acids supplementation in preterm infants. Curr Opin Pediatr 27, 165-171.

151. Cetin I, Giovannini N, Alvino G, et al. (2002) Intrauterine growth restriction is associated with changes in polyunsaturated fatty acid fetal-maternal relationships. Pediatr Res 52, 750-755.

152. Groh-Wargo S, Jacobs J, Auestad N, et al. (2005) Body composition in preterm infants who are fed long-chain polyunsaturated fatty acids: a prospective, randomized, controlled trial. Pediatr Res 57, 712-718.
153. Zhang P, Lavoie PM, Lacaze-Masmonteil T, et al. (2014) Omega-3 long-chain polyunsaturated fatty acids for extremely preterm infants: a systematic review. Pediatrics 134, 120-134.

154. Yeung MY (2006) Postnatal growth, neurodevelopment and altered adiposity after preterm birth-from a clinical nutrition perspective. Acta Paediatr 95, 909-917.

155. Azain MJ (2004) Role of fatty acids in adipocyte growth and development. J Anim Sci 82, 916-924.

156. Ruzickova J, Rossmeisl M, Prazak T, et al. (2004) Omega-3 PUFA of marine origin limit diet-induced obesity in mice by reducing cellularity of adipose tissue. Lipids 39, 1177-1185.

157. Clifton PM \& Nestel PJ (1998) Relationship between plasma insulin and erythrocyte fatty acid composition. Prostaglandins Leukot Essent Fatty Acids 59, 191-194.

158. Das UN (2002) Is metabolic syndrome $X$ an inflammatory condition? Exp Biol Med 227, 989-997.

159. Sauer N, Mosenthin R \& Bauer E (2011) The role of dietary nucleotides in single-stomached animals. Nutr Res Rev 24, 46-59.

160. Uauy R (1989) Dietary nucleotides and requirements in early life. In Textbook of Gastroenterology and Nutrition in Infancy, 2nd ed. pp. 265-280 [E Lebenthal, editor]. New York: Raven Press.

161. Sauer N, Eklund M, Bauer E, et al. (2012) The effects of pure nucleotides on performance, humoral immunity, gut structure and numbers of intestinal bacteria of newly weaned pigs. J Anim Sci 90, 3126-3134.

162. Che L, Hu L, Liu Y, et al. (2016) Dietary nucleotides supplementation improves the intestinal development and immune function of neonates with intra-uterine growth restriction in a pig model. PLOS ONE 11, e0157314.

163. Savaiano DA \& Clifford AJ (1981) Adenine, the precursor of nucleic acids in intestinal cells unable to synthesize purines de novo. J Nutr 111, 1816-1822.

164. Lapillonne A, Salle BL, Glorieux FH, et al. (2004) Bone mineralization and growth are enhanced in preterm infants fed an isocaloric, nutrient-enriched preterm formula through term. Am J Clin Nutr 80, 1595-1603.

165. Silverwood RJ, Pierce M, Hardy R, et al. (2013) Low birth weight, later renal function, and the roles of adulthood blood pressure, diabetes, and obesity in a British birth cohort. Kidney Int 84, 1262-1270.

166. Kositamongkol S, Suthutvoravut U, Chongviriyaphan N, et al. (2011) Vitamin A and E status in very low birth weight infants. J Perinatol 31, 471-476.

167. Agarwal R, Virmani D, Jaipal ML, et al. (2012) Vitamin D status of low birth weight infants in Delhi: a comparative study. $J$ Trop Pediatr 58, 446-450.

168. Mactier H \& Weaver LT (2005) Vitamin A and preterm infants: what we know, what we don't know, and what we need to know. Arch Dis Child Fetal Neonatal Ed 90, 103-108.

169. Darlow BA \& Graham PJ (2007) Vitamin A supplementation to prevent mortality and short and long-term morbidity in very low birthweight infants. Cochrane Database Syst Rev, issue 4, CD000501.

170. Brion LP, Bell EF \& Raghuveer TS (2003) Vitamin E supplementation for prevention of morbidity and mortality in preterm infants. Cochrane Database Syst Rev, issue 3, CD003665.

171. Natarajan CK, Sankar MJ, Agarwal R, et al. (2014) Trial of daily vitamin D supplementation in preterm infants. Pediatrics 133, e628-e634.

172. Senterre J, Putet G, Salle B, et al. (1983) Effects of vitamin D and phosphorus supplementation on calcium retention in preterm infants fed banked human milk. J Pediatr 103, 305-307. 
173. Mathur NB, Saini A \& Mishra TK (2016) Assessment of adequacy of supplementation of vitamin D in very low birth weight preterm neonates: a randomized controlled trial. J Trop Pediatr 62, 429-435.

174. Palmer C, Bik EM, DiGiulio DB, et al. (2007) Development of the human infant intestinal microbiota. PLoS Biol 5, e177.

175. Sari FN, Dizdar EA, Oguz S, et al. (2011) Oral probiotics: Lactobacillus sporogenes for prevention of necrotizing enterocolitis in very low-birth weight infants: a randomized, controlled trial. Eur J Clin Nutr 65, 434-439.

176. Oncel MY, Arayici S, Sari FN, et al. (2015) Comparison of Lactobacillus reuteri and nystatin prophylaxis on Candida colonization and infection in very low birth weight infants. I Matern Fetal Neonatal Med 28, 1790-1794.

177. Hartel C, Pagel J, Rupp J, et al. (2014) Prophylactic use of Lactobacillus acidophilus/Bifidobacterium infantis probiotics and outcome in very low birth weight infants. J Pediatr 165, 285-289.e281.

178. Yamasaki C, Totsu S, Uchiyama A, et al. (2012) Effect of Bifidobacterium administration on very-low-birthweight infants. Pediatr Int 54, 651-656.

179. Li Y, Shimizu T, Hosaka A, et al. (2004) Effects of Bifidobacterium breve supplementation on intestinal flora of low birth weight infants. Pediatr Int 46, 509-515.

180. Wang Q, Dong J \& Zhu Y (2012) Probiotic supplement reduces risk of necrotizing enterocolitis and mortality in preterm very low-birth-weight infants: an updated metaanalysis of 20 randomized, controlled trials. J Pediatr Surg 47, 241-248.

181. Marques TM, Wall R, Ross RP, et al. (2010) Programming infant gut microbiota: influence of dietary and environmental factors. Curr Opin Biotechnol 21, 149-156.

182. Chapman CM, Gibson GR \& Rowland I (2011) Health benefits of probiotics: are mixtures more effective than single strains? Eur J Nutr 50, 1-17.

183. Braga TD, da Silva GA, de Lira PI, et al. (2011) Efficacy of Bifidobacterium breve and Lactobacillus casei oral supplementation on necrotizing enterocolitis in very-low-birthweight preterm infants: a double-blind, randomized, controlled trial. Am J Clin Nutr 93, 81-86.

184. Saengtawesin V, Tangpolkaiwalsak R \& Kanjanapattankul W (2014) Effect of oral probiotics supplementation in the prevention of necrotizing enterocolitis among very low birth weight preterm infants. J Med Assoc Thai 97, Suppl. 6, S20-S25.

185. Lin HC, Hsu CH, Chen HL, et al. (2008) Oral probiotics prevent necrotizing enterocolitis in very low birth weight preterm infants: a multicenter, randomized, controlled trial. Pediatrics 122, 693-700.

186. Al-Hosni M, Duenas M, Hawk M, et al. (2012) Probioticssupplemented feeding in extremely low-birth-weight infants. J Perinatol 32, 253-259.

187. Boehm G, Lidestri M, Casetta P, et al. (2002) Supplementation of a bovine milk formula with an oligosaccharide mixture increases counts of faecal bifidobacteria in preterm infants. Arch Dis Child Fetal Neonatal Ed 86, F178-F181.

188. Westerbeek EA, van Elburg RM, van den Berg A, et al. (2008) Design of a randomised controlled trial on immune effects of acidic and neutral oligosaccharides in the nutrition of preterm infants: carrot study. BMC Pediatr 8, 46.

189. Riskin A, Hochwald O, Bader D, et al. (2010) The effects of lactulose supplementation to enteral feedings in premature infants: a pilot study. J Pediatr 156, 209-214.

190. Dilli D, Aydin B, Fettah ND, et al. (2015) The propre-save study: effects of probiotics and prebiotics alone or combined on necrotizing enterocolitis in very low birth weight infants. J Pediatr 166, 545-551.e1

191. Nandhini LP, Biswal N, Adhisivam B, et al. (2016) Synbiotics for decreasing incidence of necrotizing enterocolitis among preterm neonates - a randomized controlled trial. $J$ Matern Fetal Neonatal Med 29, 821-825.

192. Gautron L \& Elmquist JK (2011) Sixteen years and counting: an update on leptin in energy balance. J Clin Invest 121, 2087-2093.

193. Djiane J \& Attig L (2008) Role of leptin during perinatal metabolic programming and obesity. J Physiol Pharmacol 59, Suppl. 1, 55-63.

194. Attig L, Djiane J, Gertler A, et al. (2008) Study of hypothalamic leptin receptor expression in low-birth-weight piglets and effects of leptin supplementation on neonatal growth and development. Am J Physiol Endocrinol Metab 295, E1117-E1125.

195. Jaquet D, Leger J, Levy-Marchal C, et al. (1998) Ontogeny of leptin in human fetuses and newborns: effect of intrauterine growth retardation on serum leptin concentrations. J Clin Endocrinol Metab 83, 1243-1246.

196. Morise A, Seve B, Mace K, et al. (2009) Impact of intrauterine growth retardation and early protein intake on growth, adipose tissue, and the insulin-like growth factor system in piglets. Pediatr Res 65, 45-50.

197. Shulman RJ (1990) Oral insulin increases small intestinal mass and disaccharidase activity in the newborn miniature pig. Pediatr Res 28, 171-175.

198. Xu RJ, Mellor DJ, Birtles MJ, et al. (1994) Effects of oral IGF-I or IGF-II on digestive organ growth in newborn piglets. Biol Neonate 66, 280-287.

199. Houle VM, Schroeder EA, Odle J, et al. (1997) Small intestinal disaccharidase activity and ileal villus height are increased in piglets consuming formula containing recombinant human insulin-like growth factor-I. Pediatr Res 42, 78-86.

200. Burrin DG, Wester TJ, Davis TA, et al. (1996) Orally administered IGF-I increases intestinal mucosal growth in formula-fed neonatal pigs. Am J Physiol 270, R1085-R1091.

201. Schoknecht PA, Ebner S, Skottner A, et al. (1997) Exogenous insulin-like growth factor-I increases weight gain in intrauterine growth-retarded neonatal pigs. Pediatr Res 42, 201-207.

202. Beardsall K, Ogilvy-Stuart AL, Frystyk J, et al. (2007) Early elective insulin therapy can reduce hyperglycemia and increase insulin-like growth factor-I levels in very low birth weight infants. J Pediatr 151, 611-617.e611.

203. Fritz JV, Desai MS, Shah P, et al. (2013) From meta-omics to causality: experimental models for human microbiome research. Microbiome 1, 14.

204. Meurens F, Summerfield A, Nauwynck H, et al. (2012) The pig: a model for human infectious diseases. Trends Microbiol 20, 50-57. 